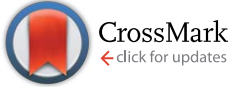

Cite this: RSC Adv., 2017, 7, 13689

Received 6th November 2016 Accepted 20th February 2017

DOI: $10.1039 / c 6 r a 26402 f$

rsc.li/rsc-advances

\title{
Dye-sensitized solar cells based on cobalt- containing room temperature ionic liquid redox shuttles $\uparrow$
}

\author{
Zhenyong Wang, $\$$ Lei Wang, \$ Ye Zhang, Jiangna Guo, Hao Li and Feng Yan*
}

An imidazolium-based co-containing room temperature ionic liquid, bis(3-butyl-1-methylimidazolium) tetraisothiocyanato cobalt $[\mathrm{BMI}]_{2}\left[\mathrm{Co}(\mathrm{NCS})_{4}\right]$, was synthesized and characterized. The prepared $[B M]_{2}\left[\mathrm{Co}(\mathrm{NCS})_{4}\right] / 1$-propyl-3-methylimidazolium iodine (PMII) hybrid redox couple showed higher redox potential than that of the iodide/triiodide $\left(\mathrm{I}^{-} / \mathrm{I}_{3}{ }^{-}\right)$redox couple. The resultant dye-sensitized solar cells (DSSCs) containing the $[\mathrm{BMI}]_{2}\left[\mathrm{Co}(\mathrm{NCS})_{4}\right] / \mathrm{PMIl}$ hybrid redox couple exhibited an average overall power conversion efficiency of $8.1 \%$ under simulated air mass 1.5 solar spectrum illumination at $100 \mathrm{~mW} \mathrm{~cm}^{-2}$, which is higher than that of traditional $\mathrm{PMII} / \mathrm{I}_{2}$ based electrolytes probably due to the enhancement of the $V_{\mathrm{oc}}$ values of the hybrid electrolytes. Furthermore, the cell based on the $[\mathrm{BMI}]_{2}\left[\mathrm{Co}(\mathrm{NCS})_{4}\right] / \mathrm{PMIl}$ hybrid redox couple tested in this study showed excellent long-term stability under ambient conditions over 120 days.

\section{Introduction}

Dye-sensitized solar cells (DSSCs) have been considered a feasible alternative to traditional silicon-based solar cells because of their high-efficiency, easy-to-handle fabrication, and relatively low production cost. ${ }^{1-6}$ Although the traditional electrolytes based on iodide/triiodide $\left(\mathrm{I}^{-} / \mathrm{I}_{3}{ }^{-}\right)$work efficiently in DSSCs, disadvantages such as corrosion of metal-based current collectors (silver or copper), sublimation of iodine, and absorption of visible light, limit the large scale production and commercial application of DSSCs. ${ }^{7,8}$ Therefore, it is desirable to develop alternative elemental iodine-free redox couples. Several promising redox mediators, including ferricinium/ferrocene $\left(\mathrm{Fc}^{+} / \mathrm{Fc}\right){ }^{9,10} \mathrm{Co}^{\mathrm{II} / \mathrm{III}}$ polypyridyl complexes, ${ }^{11-16}$ copper complexes, ${ }^{17-19}$ pseudo halogens $\left((\mathrm{SeCN})_{2} / \mathrm{SeCN}^{-}, \quad(\mathrm{SCN})_{2} /\right.$ $\left.\mathrm{SCN}^{-}\right){ }^{20-22}$ binary redox couples based on [Co((MeIm-Bpy) $\left.\left.\mathrm{PF}_{6}\right)_{3}\right]^{2+/ 3+}$ and $\mathrm{I}^{-}, 23$ [MeIm-TEMPO $][$ TFSI $]$ and $\mathrm{I}^{-}$(ref. 24) have been extensively studied.

Among the alternative redox couples studied, $\mathrm{Co}^{\mathrm{II} / \mathrm{III}}$ complexes have attracted much attentions due to their low visible light absorption, non-corrosiveness towards current collectors, and easy tuning of their redox potentials. These traits

Jiangsu Key Laboratory of Advanced Functional Polymer Design and Application, Department of Polymer Science and Engineering, College of Chemistry, Chemical Engineering and Materials Science, Soochow University, Suzhou 215123, P. R. China.E-mail: fyan@suda.edu.cn

$\dagger$ Electronic supplementary information (ESI) available: ${ }^{1} \mathrm{H}$ NMR characterization of the synthesized compounds and TGA analysis of prepared AEMs. See DOI: 10.1039/c6ra26402f

\$ Authors with equal contributions. make $\mathrm{Co}^{\mathrm{II} / \mathrm{III}}$ polypyridyl complexes suitable candidates for replacing $\mathrm{I}^{-} / \mathrm{I}_{3}{ }^{-} \cdot{ }^{\mathbf{1 1}, \mathbf{1 2}, 25-27}$ For example, photoelectric conversion efficiencies as high as $13 \%$ have been obtained with a $\mathrm{Co}^{\mathrm{II} / \mathrm{III}}$ tris(bipyridyl)-based redox electrolyte. ${ }^{28}$

Metal-containing ionic liquids combine properties of ionic liquids with magnetic, photophysical/optical, or catalytic properties that emanate from the incorporated metal. Transition or rare-earth metal-containing ionic liquids exhibit interesting magnetic, ${ }^{29-31}$ fluorescence, ${ }^{32-35}$ catalytic $^{36,37}$ and electrochromic $^{38}$ properties. However, applications of redoxactive metal-containing ionic liquids in electrochemical applications are still rare. ${ }^{39}$

Herein an imidazolium-based co-containing room temperature ionic liquid, bis(3-butyl-1-methylimidazolium) tetraisothiocyanato cobalt $[\mathrm{BMI}]_{2}\left[\mathrm{Co}(\mathrm{NCS})_{4}\right]$ (see Scheme 1), which contains doubly charged tetraisothiocyanatocobaltate(II) anions, was synthesized and for the first time be applied as a redox mediator for DSSCs. These DSSCs based on the $\left[\mathrm{Co}^{2+}(\mathrm{NCS})_{4}\right]^{2-} /\left[\mathrm{Co}^{3+}(\mathrm{NCS})_{4}\right]^{-} / \mathrm{I}^{-}$hybrid redox couple exhibited an overall power conversion efficiency of about $8.1 \%$ under simulated air mass 1.5 solar spectrum illumination at $100 \mathrm{~mW}$ $\mathrm{cm}^{-2}$, and an excellent long-term stability if compared with traditional $\mathrm{I}^{-} / \mathrm{I}_{3}{ }^{-}$based DSSCs.

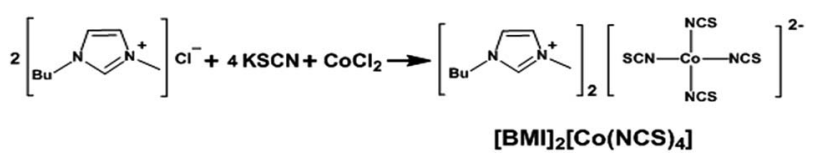

Scheme 1 General synthetic procedures for the preparation of $[\mathrm{BMI}]_{2}\left[\mathrm{Co}(\mathrm{NCS})_{4}\right]$ ionic liquid. 


\section{Experimental}

\section{Materials}

Cobalt chloride $\left(\mathrm{CoCl}_{2}\right)$, potassium thiocyanate (KSCN), nitromethane $\left(\mathrm{CH}_{3} \mathrm{NO}_{2}\right)$ and dichloromethane $\left(\mathrm{CH}_{2} \mathrm{Cl}_{2}\right)$ were purchased from Alfa Aesar and used without further purification. Nitrosonium tetrafluoroborate $\left(\mathrm{NOBF}_{4}\right)$, 1-butyl-3- methylimidazoliumchloride (BMICl), and iodide (PMII) were purchased from Merck. $\mathrm{H}_{2} \mathrm{PtCl}_{6}$ was purchased from Aldrich. cis-Diisothiocyanato-bis(2,2'-bipyridyl-4,4'-dicarboxylic acid) ruthenium(II) bis(tetrabutylammonium) (D205) was purchased from Solaronix SA (Switzerland). Fluorine-doped tin oxide overlayer (FTO) glass electrodes $\left(15 \Omega \mathrm{sq}^{-1}\right)$, slurries containing $20 \mathrm{~nm}$-sized mesoporous and $200 \mathrm{~nm}$-diameter light-scattering colloidal $\mathrm{TiO}_{2}$ were purchased from Dalian Hepat Chroma Solar Tech. Co., Ltd (China).

\section{Synthesis of $[\mathrm{BMI}]_{2}\left[\mathrm{Co}(\mathrm{NCS})_{4}\right]$}

$[\mathrm{BMI}]_{2}\left[\mathrm{Co}(\mathrm{NCS})_{4}\right]$ was synthesized as previously reported. ${ }^{29}$ Potassium thiocyanate, $2.61 \mathrm{~g}(26.84 \mathrm{mmol})$, and $2.34 \mathrm{~g}$ (13.42 mmol) 1-butyl-3-methylimidazolium chloride were dissolved in $100 \mathrm{~mL}$ water, to which $0.85 \mathrm{~g}(6.65 \mathrm{mmol})$ cobalt-chloride was added, and the reaction mixture was stirred at room temperature until the solution color turned dark blue. The mixture was then extracted with nitromethane several times untill the aqueous layer became colorless; the combined organic layers were dried (over magnesium sulfate) and became an inky and opaque viscous liquid. This viscous product was washed with dichloromethane and then dried in a vacuum oven at $60{ }^{\circ} \mathrm{C}$ for $24 \mathrm{~h}$ to obtain the dark blue ionic liquid. Yield: $2.8 \mathrm{~g}$ (75.6\%). FTIR (KBr) (cm $\left.{ }^{-1}\right): 3146,3107,2959,2933,2872,2069,1580$, 1462, 1383, 1338, 1165, 1108, 1025, 963, 832, 746, 649, 620. Elemental analysis calcd: C, $42.17 \% ; \mathrm{H}, 5.31 \% ; \mathrm{N}, 19.67 \%$. Found: C, 42.33\%; H, 5.33\%; N, 19.34\%.

\section{Preparation of electrolytes}

The compositions of the electrolytes applied in this work are listed in Table 1.

\section{Fabrication of the DSSCs ${ }^{40-42}$}

The cleaned FTO glass was covered with perforated adhesive tape to control the thickness and the area of mesoporous $\mathrm{TiO}_{2}$ film, the $\mathrm{TiO}_{2}$ film area is about $0.283 \mathrm{~cm}^{2}$. The FTO glass was immersed into a $40 \mathrm{mM}$ aqueous $\mathrm{TiCl}_{4}$ solution at $70{ }^{\circ} \mathrm{C}$ for $30 \mathrm{~min}$ and washed with water and ethanol. Then two layers of $\mathrm{TiO}_{2}$ particles were deposited onto cleaned FTO glass and used as photoelectrodes. A $5 \mu \mathrm{m}$-thick film of $20 \mathrm{~nm}$-sized $\mathrm{TiO}_{2}$ particles was deposited onto the FTO glass electrode by the doctor-blade technique. The film was dried at $125^{\circ} \mathrm{C}$ for $5 \mathrm{~min}$. Then, a second $3 \mu \mathrm{m}$-thick layer of $200 \mathrm{~nm}$ light-scattering anatase particles were coated on the top of the first $\mathrm{TiO}_{2}$ layer. The resulting $\mathrm{TiO}_{2}$ films were annealed at $500{ }^{\circ} \mathrm{C}$ for $30 \mathrm{~min}$. The fabricated two layers $\mathrm{TiO}_{2}$ film were once again treated with $40 \mathrm{mM}$ aqueous $\mathrm{TiCl}_{4}$ solution, and then rinsed with water and ethanol and sintered at $500{ }^{\circ} \mathrm{C}$ for $30 \mathrm{~min}$. After cooling to $80^{\circ} \mathrm{C}$, the obtained $\mathrm{TiO}_{2}$ electrode was immersed in $0.5 \mathrm{mM}$ D205 solution in acetonitrile and tert-butyl alcohol at room temperature for $24 \mathrm{~h}$. Then the dye-coated $\mathrm{TiO}_{2}$ electrode was washed with anhydrous ethanol and dried with nitrogen stream. To prepare the Pt counter electrode, two drops of $2 \mathrm{mM} \mathrm{H}_{2} \mathrm{PtCl}_{6}$ in ethanol was placed onto the cleaned FTO glass substrate, followed by drying and annealing at $400{ }^{\circ} \mathrm{C}$ for $15 \mathrm{~min}$.

DSSCs were fabricated by sandwiching gel electrolytes between a dye-sensitized $\mathrm{TiO}_{2}$ electrode and a Pt counter electrode, which were separated by a $25 \mu \mathrm{m}$ thick hot melt ring (Surlyn, Dupont) and sealed by heating. The cell internal space was filled with electrolytes via vacuum backfilling. The electrolyte injection hole on the thermally platinized FTO counter electrode was finally sealed with a Surlyn sheet and a thin glass by heating.

\section{Characterization and photovoltaic measurements}

Fourier-transform infrared (FTIR) spectra were recorded on a ProStar LC240 FTIR spectrometer in the range of 4000-400 $\mathrm{cm}^{-1}$. UV-vis spectra were measured on a TU-1800 SPC spectrophotometer. Cyclic voltammetry was conducted on CHI660c electrochemical workstations with a conventional threeelectrode system. The reference electrode was $\mathrm{Ag} / \mathrm{Ag}^{+}$, the

Table 1 Photovoltaic performance of DSSCs under simulated AM 1.5 solar spectrum illumination at $100 \mathrm{mM} \mathrm{cm}^{-2}$. The DSSCs were characterized immediately after the fabrication and the average performance of three devices (with standard deviations in parentheses) is provided

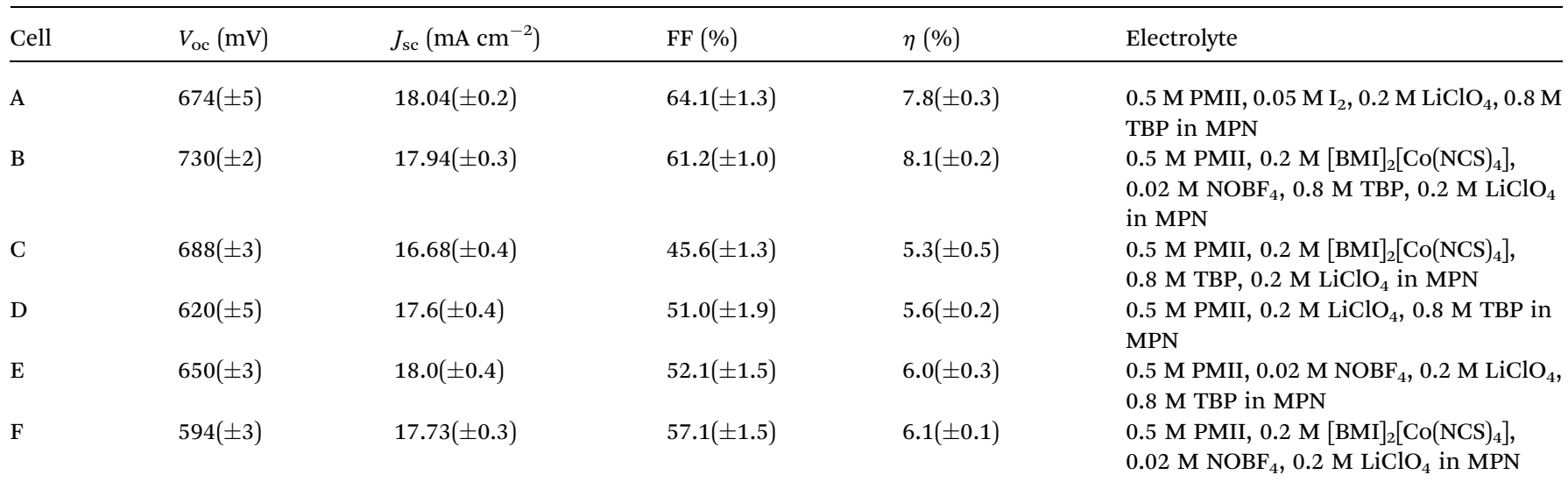


counter-electrode was a Pt wire and the working electrode was $1.6 \mathrm{~mm}$ diameter Pt electrode. The supporting electrolyte was $0.1 \mathrm{M} \mathrm{LiClO}_{4}$ in $\mathrm{ACN}$ and the scan rate was $50 \mathrm{mV} \mathrm{s}^{-1}$. The photocurrent density-voltage $(J-V)$ curves of the assembled DSSCs shielded by an aluminium foil mask with an aperture area of $\sim 0.1 \mathrm{~cm}^{2}$ were measured with a digital source meter (Keithley, model 2612) under simulated air mass (AM) 1.5 solar

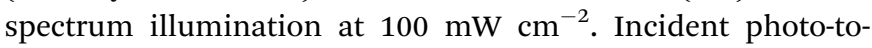
current conversion efficiency (IPCE) plotted as a function of excitation wavelength was recorded on a Keithley 2612 source meter under the irradiation of a Xenon lamp with a monochromator (Oriel Cornerstone ${ }^{\mathrm{TM}} 260$ 1/4). The photo electrochemical parameters, such as the fill factor (FF) and light-toelectricity conversion efficiency $(\eta)$ were calculated according to the previous reports. ${ }^{43}$

The electrochemical impedance spectra (EIS) of the devices were carried out on a CHI660c electrochemical workstation using the AC impedance method at the forward bias voltage for the impedance measurement was $-0.70 \mathrm{~V}$ and the frequency ranged from 0.01-105 $\mathrm{Hz}$ under dark condition and the amplitude is $5 \mathrm{mV}$. The Mott-Schottky plots were tested with a CHI660c electrochemical workstation. The photoelectrochemical parameters, such as the fill factor (FF) and the light-to-electricity conversion efficiency (PCE), were calculated according to previous reports. ${ }^{43}$

\section{Results and discussion}

Scheme 1 shows the chemical structure and general synthetic procedure of $[\mathrm{BMI}]_{2}\left[\mathrm{Co}(\mathrm{NCS})_{4}\right]$. The details of the synthesis are described in Experimental section. It has already been demonstrated that redox potential plays a very important role in determining the photovoltaic performance of redox couples in DSSCs. ${ }^{12}$ Here, the cyclic voltammetry(CV) scans were calibrated using a ferrocene/ferrocenium $\left(\mathrm{Fc} / \mathrm{Fc}^{+}\right)$couple, and the redox potentials were converted to those versus a normal hydrogen electrode (NHE) reference scale by adding a constant of $0.63 \mathrm{~V}$ as shown in Fig. $1 .^{44}$ The redox potential of

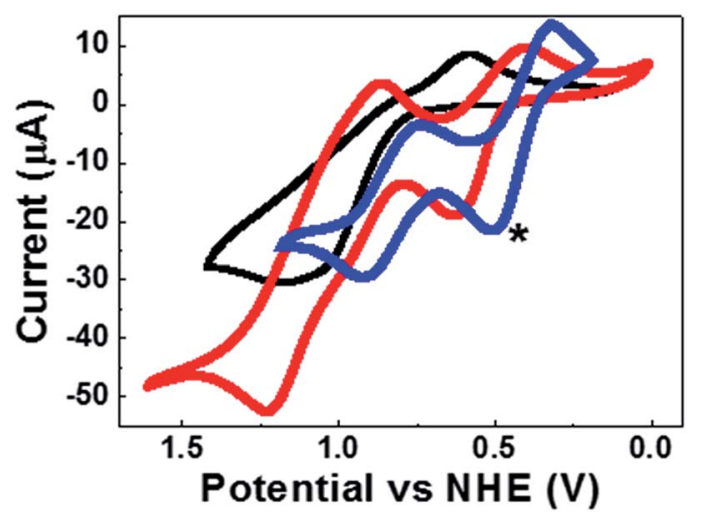

Fig. 1 Cyclic voltammogram of $5 \mathrm{mM}[\mathrm{BMl}]_{2}\left[\mathrm{Co}(\mathrm{NCS})_{4}\right]$ (black), $[\mathrm{BMI}]_{2}\left[\mathrm{Co}(\mathrm{NCS})_{4}\right] / \mathrm{PMII}\left(1: 2.5\right.$, molar ratio, red) and $\mathrm{PMII} / \mathrm{I}_{2}$ (blue) in acetonitrile. The measurements were performed using $0.1 \mathrm{M} \mathrm{LiClO}_{4}$ as the supporting electrolyte at a scan rate of $50 \mathrm{mV} \mathrm{s}^{-1}$.
$\left[\mathrm{Co}^{2+}(\mathrm{NCS})_{4}\right]^{2-} /\left[\mathrm{Co}^{3+}(\mathrm{NCS})_{4}\right]^{-}$was determined to be $0.86 \mathrm{~V}$ versus NHE.

In order to understand the redox behavior of this hybrid redox mediator, the $\mathrm{CV}$ of $\mathrm{PMII} /[\mathrm{BMI}]_{2}\left[\mathrm{Co}(\mathrm{NCS})_{4}\right]$ and $\mathrm{PMII} / \mathrm{I}_{2}$ hybrid redox couples was studied too. The redox potentials of $\mathrm{PMII} / \mathrm{I}_{2}$ and $\mathrm{PMII} /[\mathrm{BMI}]_{2}\left[\mathrm{Co}(\mathrm{NCS})_{4}\right]$ were determined to be $0.42 \mathrm{~V}$ and $0.50 \mathrm{~V}$, respectively. Energy loss incurred during dye regeneration is one of the main factors limiting the performance of DSSCs. ${ }^{45}$ Since the redox potential of the dye is higher than that of the redox couple, a higher redox potential of redox mediator would reduce the excessive driving force for the dyeregeneration reaction and, therefore, beneficially improve the open-circuit voltage of the DSSC. ${ }^{46}$ Thus, it is not surprising that the $\mathrm{PMI} /[\mathrm{BMI}]_{2}\left[\mathrm{Co}(\mathrm{NCS})_{4}\right]$ hybrid redox couple yields the highest open-circuit voltage $\left(V_{\text {oc }}\right)$ of the devices fabricated.

The photovoltaic parameters of DSSCs based on various redox couples under simulated AM 1.5 solar spectrum illumination at $100 \mathrm{~mW} \mathrm{~cm} \mathrm{~cm}^{-2}$ were measured (Fig. 2). The obtained photovoltaic data are summarized in Table 1 . It can be clearly seen that the device based on the $\mathrm{I}^{-} / \mathrm{I}_{3}{ }^{-}$redox couple (Cell A) showed a short-circuit current density $\left(J_{\mathrm{sc}}\right)$ of $18.04 \mathrm{~mA} \mathrm{~cm}{ }^{-2}$, a $V_{\text {oc }}$ of $674 \mathrm{mV}$, a fill factor (FF) of $64.1 \%$, and an overall power efficiency of about $7.8 \%$.

Ionic liquid (1-butyl-3-methylimidazolium tetrafluoroborate $\left([\mathrm{BMI}]\left[\mathrm{BF}_{4}\right]\right)$ ) electrolyte DSSCs based on PMII/[BMI $]_{2}\left[\mathrm{Co}(\mathrm{NCS})_{4}\right]$ hybrid redox were first studied. However, consider the poor fill factor (FF) and low efficiency of the devices (Fig. S1 and Table $\mathrm{S} 1 \dagger$ ), 3-methoxypropionitrile (MPN) was chosen as the solvent electrolyte for co-containing redox couple based DSSCs because of its superior advantages. In the case of the $\left[\mathrm{Co}^{2+}(\mathrm{NCS})_{4}\right]^{2-}$ / $\left[\mathrm{Co}^{3+}(\mathrm{NCS})_{4}\right]^{-} / \mathrm{I}^{-}$hybrid redox couple (Cell B), the $V_{\text {oc }}$ value of the device was increased from 674 (Cell A) to $730 \mathrm{mV}$, and an average overall power conversion efficiency of $8.1 \%$ was achieved.

Cell C $\left(\left[\mathrm{Co}^{2+}(\mathrm{NCS})_{4}\right]^{2-} / \mathrm{I}^{-}\right.$hybrid redox couple without addition of an oxidant $\left.\mathrm{NOBF}_{4}\right)$, Cell D ( $\mathrm{I}^{-}$only without addition of $\left.\mathrm{I}_{2}\right)$ and Cell $\mathrm{E}$ (without addition of $\left[\mathrm{Co}^{2+}(\mathrm{NCS})_{4}\right]^{2-}$ ) were further assembled to compare the effects of hybrid redox couples on the

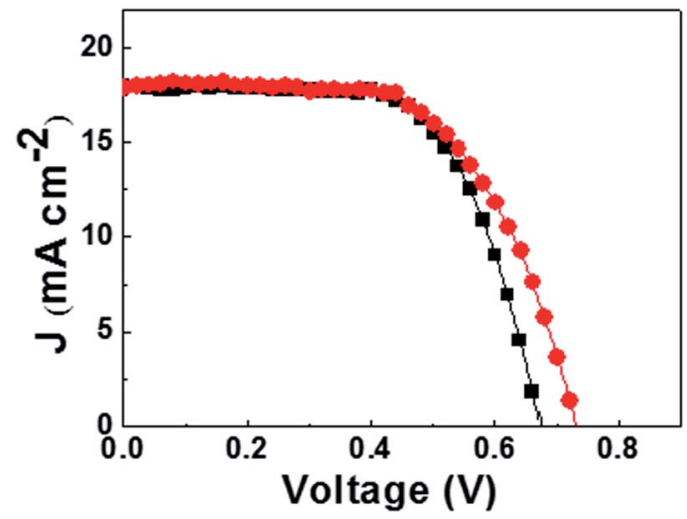

Fig. 2 The J-V curves of Cell A (- - -) and Cell B (- - ) under the simulated AM 1.5 solar spectrum irradiation at $100 \mathrm{~mW} \mathrm{~cm}^{-2}$. Cells were tested using an aluminum foil mask with an aperture area of 0.1 $\mathrm{cm}^{2}$. 
cell performances. It can be seen that the power conversion efficiencies of Cells C, D and E are much lower than that of Cell B (Fig. S2 $\dagger$ ) probably due to the unbalanced redox couples.

Among the reported studies, none of the published work employing dual redox systems had clearly explained the electrochemical processes. ${ }^{47}$ Here, it can be seen from the redox potentials shown in Fig. 1 that $\mathrm{I}_{3}{ }^{-}$may be present as an intermediate in the hybrid redox system. Therefore, we hypothesize the redox mechanism functions as follows: (1) first, under light illumination, the photoexcitation of the dye (D) (eqn (1)) injects electrons into the conduction band of the $\mathrm{TiO}_{2}$ layer (eqn (2)). (2) Then the charge will transfer to the counter electrode (eqn (3)) and the oxidized molecular dye is restored to its ground state by electron donation from an electrolyte-containing redox system, reduced mainly by $\left[\mathrm{Co}^{2+}(\mathrm{NCS})_{4}\right]^{2-}$ and formed $\left[\mathrm{Co}^{3+}(\mathrm{NCS})_{4}\right]^{-}$(eqn (4)). (3) The redox potential of the $\left[\mathrm{Co}(\mathrm{NCS})_{4}\right]^{2-}$ is more positive than that of the $\mathrm{I}^{-} / \mathrm{I}_{3}{ }^{-}$redox couple, $\mathrm{I}^{-}$is then easily reduced by $\left[\mathrm{Co}^{3+}(\mathrm{NCS})_{4}\right]^{-}$to $\mathrm{I}_{3}{ }^{-}$(eqn (5)). (4) After that, the electron injected into the conduction band arrives at the anode and then flows through the external load to the cathode. (5) Finally, $\mathrm{I}_{3}{ }^{-}$is reduced to iodide at the counter electrode (eqn (6)).

$$
\begin{gathered}
\mathrm{D} / \mathrm{TiO}_{2}+h \nu \rightarrow \mathrm{D}^{*} / \mathrm{DC} \\
\mathrm{D}^{*} / \mathrm{DC} \rightarrow \mathrm{D}^{+} / \mathrm{TiO}_{2}+e_{\mathrm{cb}}{ }^{-} \\
e_{\mathrm{cb}}{ }^{-} \rightarrow e_{\mathrm{ce}}{ }^{-} \\
\mathrm{D}^{+} / \mathrm{TiO}_{2}+\mathrm{Co}^{2+} \rightarrow \mathrm{D} / \mathrm{TiO}_{2}+\mathrm{Co}^{3+}
\end{gathered}
$$
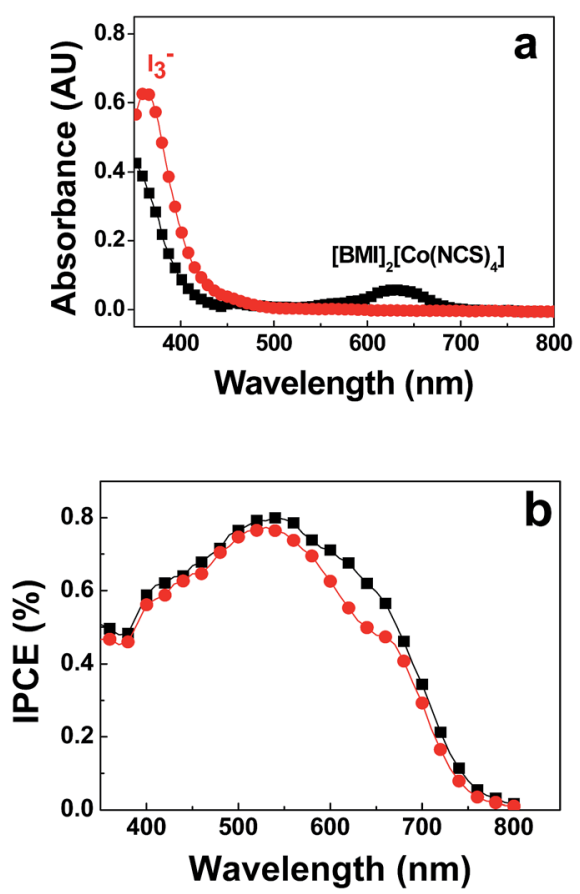

Fig. 3 (a) UV-vis spectra of $0.2 \mathrm{mM}[\mathrm{BMI}]_{2}\left[\mathrm{Co}(\mathrm{NCS})_{4}\right], 0.02 \mathrm{M} \mathrm{NOBF}_{4}$ and 0.5 M PMII (- -) and 0.5 M PMII and 0.05 $\mathrm{M} \mathrm{NOBF}_{4}(-\mathbf{-}-)$ in acetonitrile (diluted 1000 times); (b) the IPCE curves of Cell A (- $\mathbf{-}-)$ and Cell B (-0).

$$
\begin{gathered}
2 \mathrm{Co}^{3+}+3 \mathrm{I}^{-} \rightarrow \mathrm{I}_{3}^{-}+2 \mathrm{Co}^{2+} \\
\mathrm{I}_{3}^{-}+2 e_{\mathrm{cb}}{ }^{-} \rightarrow 3 \mathrm{I}^{-} \\
e_{\mathrm{cb}}{ }^{-}+\mathrm{D}^{*} \rightarrow \mathrm{D}
\end{gathered}
$$

Fig. 3a shows the UV-Vis spectra of the electrolytes. It can be seen that the formation of $\mathrm{I}_{3}{ }^{-}$in $\mathrm{PMII} / \mathrm{BMI}_{2}\left[\mathrm{Co}(\mathrm{NCS})_{4}\right] / \mathrm{NOBF}_{4}$ electrolyte is well hindered compared with $\mathrm{PMII} / \mathrm{I}_{2}$ electrolyte. However, a low concentration of $\mathrm{I}_{3}{ }^{-}$in $\left[\mathrm{Co}^{2+}(\mathrm{NCS})_{4}\right]^{2-}$ / $\left[\mathrm{Co}^{3+}(\mathrm{NCS})_{4}\right]^{-}$electrolyte did not result in a higher $J_{\text {sc }}$ value probably due to the light absorption at around $600 \mathrm{~nm}$ of $[\mathrm{BMI}]_{2}\left[\mathrm{Co}(\mathrm{NCS})_{4}\right]$ (Fig. 3a). The incident photo-to-current conversion efficiency (IPCE) spectra of Cell B and $\mathrm{C}$ were measured. As shown in Fig. 3b, Cell B showed slightly lower IPCE values compared with an $\mathrm{I}^{-} / \mathrm{I}_{3}{ }^{-}$redox couple in the visible spectrum, this can be attributed to the absorption of $[\mathrm{BMI}]_{2}[-$ $\left.\mathrm{Co}(\mathrm{NCS})_{4}\right]$ (between 560 and $670 \mathrm{~nm}$ ).

To better explain the higher $V_{\mathrm{oc}}$ of the DSSCs based on the $[\mathrm{BMI}]_{2}\left[\mathrm{Co}(\mathrm{NCS})_{4}\right]$ ionic liquid redox couple, the Mott-Schottky behavior of our $\mathrm{TiO}_{2}$ film/redox couple was obtained to determine flat-band potentials $\left(V_{\mathrm{fb}}\right.$; potential that induces zero net charge), as shown in Fig. $4 \mathrm{a}$. The $V_{\text {oc }}$ of the cells is determined from the redox potential in the electrolyte and the quasi-Fermi level, ${ }^{48}$ which increases linearly with $V_{\mathrm{fb}} \cdot{ }^{49}$ A negative shift of $V_{\mathrm{fb}}$ in Fig. 4a means a shift away from the redox potential, thereby an increase of $V_{\mathrm{oc}}$. The conduction band of our $\mathrm{TiO}_{2}$ film with the PMII/[BMI $]_{2}\left[\mathrm{Co}(\mathrm{NCS})_{4}\right]$ hybrid electrolyte (Cell B) is about $215 \mathrm{mV}$ positive that of the $\mathrm{PMII} / \mathrm{I}_{2}$ based electrolyte (Cell A).
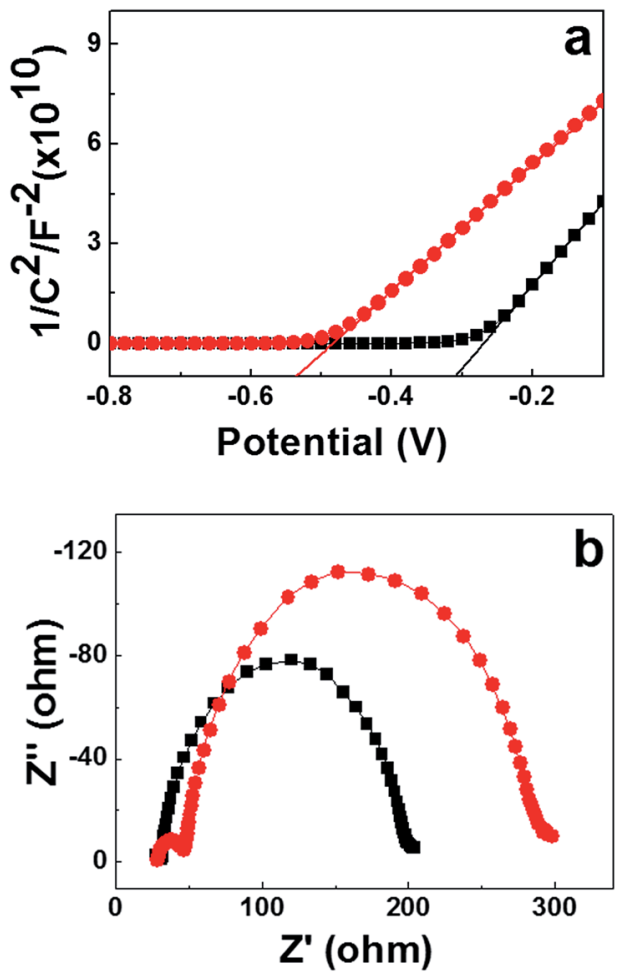

Fig. 4 (a) Mott-Schottky and (b) EIS Nyquist plots for Cell A (- - -) and Cell B (-0 -). 
Therefore, the $V_{\text {oc }}$ value of $\mathrm{PMII} /[\mathrm{BMI}]_{2}\left[\mathrm{Co}(\mathrm{NCS})_{4}\right]$ hybrid electrolyte is higher than that of the traditional $\mathrm{I}^{-} / \mathrm{I}_{3}{ }^{-}$redox couple electrolyte.

The electrochemical impedance spectroscopy (EIS) was further applied to examine the charge transfer resistance in DSSCs and for understanding recombination dynamics at the dye-coated $\mathrm{TiO}_{2} /$ electrolyte interface. Cells $\mathrm{A}$ and $\mathrm{B}$ were measured at a bias of $-0.7 \mathrm{~V}$ in the dark, as shown in Fig. $4 \mathrm{~b}$. From high to low frequency, three distorted semicircles are observed in the Nyquist plots. The distortions may be assigned to stretched exponential relaxation emanating from the fractal nature of the $\mathrm{TiO}_{2}$ porosity. ${ }^{50,51}$

Some important parameters could be obtained by fitting the EIS spectra to an electrochemical model (Table 2). ${ }^{52} R_{\mathrm{CE}}, R_{\mathrm{T}}$ and $R_{\mathrm{d}}$ represent the charge-transfer resistance at the counter electrode, the resistance of $\mathrm{TiO}_{2} / \mathrm{FTO}-\mathrm{TiO}_{2} /$ electrolyte interface, and the Nernst diffusion in electrolyte, respectively. ${ }^{6,53,54}$ It can be seen that the $R_{\mathrm{CE}}$ value of Cell $\mathrm{A}$ is lower than that of Cell $\mathrm{B}$, indicating that $\mathrm{I}^{-} / \mathrm{I}_{3}{ }^{-}$based electrolyte is easily reduced by the Pt counter electrode; this leads to a higher $\mathrm{FF}^{47}$ Future studies will seek a suitable catalyst for deposition on the counter electrode to improve the fill factor using a $\mathrm{PMII} /[\mathrm{BMI}]_{2}\left[\mathrm{Co}(\mathrm{NCS})_{4}\right]$ redox couple. In general, the bigger the semicircle in the intermediate-frequency region, the weaker the charge recombination at the photoelectrode/electrolyte interface. ${ }^{55}$ The $R_{\mathrm{T}}$ values of Cells A and B were calculated to be $166.7 \Omega$ and 240.6 $\Omega$, respectively. These results demonstrate that Cell B has a slower recombination reaction between the conduction band electrons in the $\mathrm{TiO}_{2}$ photoanode and electrolyte interface than Cell A. From Table 2, we can see that the value of $R_{\mathrm{d}}$ of Cell B is higher than that of Cell $\mathrm{A}$, indicating an increase in the conductivity. ${ }^{56,57}$ Such a difference yields a higher photo conversion efficiency. ${ }^{44}$

Consider the stability of our fabricated cells, the long-term stability test was carried out. The well sealed Cells (A, B, and E) were stored under dark conditions at room temperature. The photovoltaic performance parameters including $J_{\mathrm{sc}}, V_{\mathrm{oc}}, \mathrm{FF}$ and PCE of the cells were measured daily and the photovoltaic parameters of these DSSCs are shown in Fig. 5 . In the case of the $\mathrm{I}^{-} / \mathrm{I}_{3}{ }^{-}$redox couple (Cell A), the device exhibited an initial improvement in performance (PCE), but then there was a gradual decrease that stabilized at about $95 \%$ of the original value after 120 day. However, a slight increase $(\sim 10 \%)$ of PCE was observed for DSSCs based on PMII/[BMI $]_{2}\left[\mathrm{Co}(\mathrm{NCS})_{4}\right] / \mathrm{TBP}$ electrolyte (Cell B) throughout the 120 day stability testing. The highest overall efficiency of $8.9 \%$ under 1.5 solar spectrum illumination at $100 \mathrm{~mW} \mathrm{~cm}{ }^{-2}$ was obtained on the 30th day of testing (Fig. S3†). For comparison, Cell E, a device containing the same electrolyte as Cell B (however, without TBP), was

Table 2 The parameters obtained by fitting the EIS of the DSSCS fabricated with electrolytes $A$ and $B$

\begin{tabular}{lrrr}
\hline Cell & $R_{\mathrm{CE}} / \Omega$ & $R_{\mathrm{T}} / \Omega$ & $R_{\mathrm{d}} / \Omega$ \\
\hline A & 3.4 & 166.7 & 6.1 \\
B & 18.9 & 240.6 & 10.4
\end{tabular}

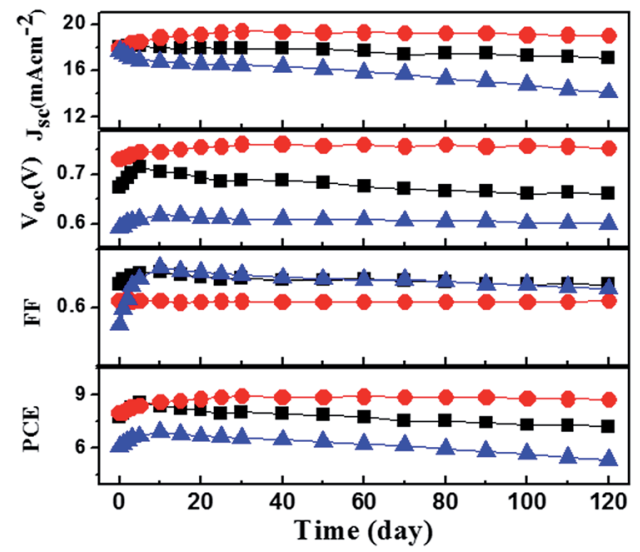

Fig. 5 Time-course variation of photovoltaic performance parameters (average of five cells) of Cell $A(-\mathbf{\square}-)$, Cell $B(-\mathbf{0}-$ ) and Cell $E$ $(-\boldsymbol{\Delta}-)$. The cell was covered with a UV cut-off filter, and irradiated at open circuit and ambient temperature.

fabricated and characterized under the same experimental conditions. It can be seen that a decrease in performance of about $10 \%$ was observed for Cell $\mathrm{E}$ after 120 day testing. Above all, we conclude that the relatively high stability of Cell B is due to the presence of TBP (as compared with Cell E).

According to the recently studied by Bach and co-workers, ${ }^{58}$ additives the long-term stability of the co-bpy electrolyte based DSSCs. ${ }^{59}$ It should be noted that the concentration of TBP $(0.8$ $\mathrm{M})$ in the electrolyte is much higher than that of $[\mathrm{BMI}]_{2}$ $\left[\mathrm{Co}(\mathrm{NCS})_{4}\right](0.2 \mathrm{M})$. Therefore, $[\mathrm{BMI}]_{2}\left[\mathrm{Co}(\mathrm{NCS})_{4}\right]$ could be replaced by a more strongly binding $[\mathrm{BMI}]_{2}\left[\mathrm{Co}(\mathrm{NCS})_{4}(\mathrm{TBP})_{2}\right]$ ligand (Scheme S1†). Such a multidentate ligand may form a very stable cobalt redox mediator under DSSC test conditions. This is the first reported example where such a cobalt-based hybrid electrolyte has provided such excellent device stability; the mechanism behind our observations was still under exploration.

\section{Conclusion}

In conclusion, a cobalt-containing room temperature ionic liquid, $[\mathrm{BMI}]_{2}\left[\mathrm{Co}(\mathrm{NCS})_{4}\right]$, was synthesized and for the first time applied as a redox mediator in DSSC electrolytes. The fabricated devices based on this $[\mathrm{BMI}]_{2}\left[\mathrm{Co}(\mathrm{NCS})_{4}\right] / \mathrm{PMII}$ hybrid redox couple and TBP exhibited a power conversion efficiency of $8.1 \%$ under AM 1.5 solar spectrum illumination at $100 \mathrm{~mW} \mathrm{~cm}^{-2}$. In addition, the devices tested in this study exhibited excellent long-term stability under ambient conditions over 120 days. Further investigations will focus on the structure-activity optimization of cobalt-containing ionic liquid-based redox mediators, as well as long-term device stability.

\section{Acknowledgements}

This work was supported by the National Science Foundation for Distinguished Young Scholars (No. 21425417), the Natural Science Foundation of China (No. 21274101), and the Project 
Funded by the Priority Academic Program Development of Jiangsu Higher Education Institutions.

\section{References}

1 B. Oregan and M. Gratzel, Nature, 1991, 353, 737-740.

2 M. Gratzel, Nature, 2001, 414, 338-344.

3 Y. Zhang, H. Li, L. Kuo, P. Dong and F. Yan, Curr. Opin. Colloid Interface Sci., 2015, 20, 406-415.

4 B. He, Q. Tang, J. Luo, Q. Li, X. Chen and H. Cai, J. Power Sources, 2014, 256, 170-177.

5 T. Deepak, G. Anjusree, S. Thomas, T. Arun, S. V. Nair and A. S. Nair, RSC Adv., 2014, 4, 17615-17638.

6 Y. Zhang, Z. Sun, S. Cheng and F. Yan, ChemSusChem, 2016, 9, 813-819.

7 G. Boschloo and A. Hagfeldt, Acc. Chem. Res., 2009, 42, 18191826.

8 J. Cong, X. Yang, L. Kloo and L. Sun, Energy Environ. Sci., 2012, 5, 9180-9194.

9 T. Daeneke, T. H. Kwon, A. B. Holmes, N. W. Duffy, U. Bach and L. Spiccia, Nat. Chem., 2011, 3, 211-215.

10 T. Daeneke, A. J. Mozer, T.-H. Kwon, N. W. Duffy, A. B. Holmes, U. Bach and L. Spiccia, Energy Environ. Sci., 2012, 5, 7090-7099.

11 S. A. Sapp, C. M. Elliott, C. Contado, S. Caramori and C. A. Bignozzi, J. Am. Chem. Soc., 2002, 124, 11215-11222.

12 J.-H. Yum, E. Baranoff, F. Kessler, T. Moehl, S. Ahmad, T. Bessho, A. Marchioro, E. Ghadiri, J.-E. Moser, C. Yi, M. K. Nazeeruddin and M. Graetzel, Nat. Commun., 2012, 3, 631 .

13 M. Xu, D. Zhou, N. Cai, J. Liu, R. Li and P. Wang, Energy Environ. Sci., 2011, 4, 4735-4742.

14 I. R. Perera, T. Daeneke, S. Makuta, Z. Yu, Y. Tachibana, A. Mishra, P. Bäuerle, C. A. Ohlin, U. Bach and L. Spiccia, Angew. Chem., Int. Ed., 2015, 54, 3758-3762.

15 Z. Sun, M. Liang and J. Chen, Acc. Chem. Res., 2015, 48, 15411550.

16 A. V. Muller, L. D. Ramos, K. P. M. Frin, K. T. de Oliveira and A. S. Polo, RSC Adv., 2016, 6, 46487-46494.

17 Y. Bai, Q. Yu, N. Cai, Y. Wang, M. Zhang and P. Wang, Chem. Commun., 2011, 47, 4376-4378.

18 T. E. Hewat, L. J. Yellowlees and N. Robertson, Dalton Trans., 2014, 43, 4127-4136.

19 A. Buttner, S. Y. Brauchli, R. Vogt, E. C. Constable and C. E. Housecroft, RSC Adv., 2016, 6, 5205-5213.

20 B. V. Bergeron, A. Marton, G. Oskam and G. J. Meyer, J. Phys. Chem. B, 2005, 109, 937-943.

21 P. Wang, S. M. Zakeeruddin, J. E. Moser, R. Humphry-Baker and M. Gratzel, J. Am. Chem. Soc., 2004, 126, 7164-7165.

22 X. Liu, Z. Cao, H. Huang, X. Liu, Y. Tan, H. Chen, Y. Pei and S. Tan, J. Power Sources, 2014, 248, 400-406.

23 D. Xu, H. Zhang, X. Chen and F. Yan, J. Mater. Chem. A, 2013, 1, 11933-11941.

24 X. Chen, D. Xu, L. Qiu, S. Li, W. Zhang and F. Yan, J. Mater. Chem. A, 2013, 1, 8759-8765.
25 H. Nusbaumer, J. E. Moser, S. M. Zakeeruddin, M. K. Nazeeruddin and M. Gratzel, J. Phys. Chem. B, 2001, 105, 10461-10464.

26 M. Ye, X. Wen, M. Wang, J. Iocozzia, N. Zhang, C. Lin and Z. Lin, Mater. Today, 2015, 18, 155-162.

27 K. Kakiage, Y. Aoyama, T. Yano, K. Oya, J.-i. Fujisawa and M. Hanaya, Chem. Commun., 2015, 51, 15894-15897.

28 A. Yella, H.-W. Lee, H. N. Tsao, C. Yi, A. K. Chandiran, M. K. Nazeeruddin, E. W.-G. Diau, C.-Y. Yeh, S. M. Zakeeruddin and M. Graetzel, Science, 2011, 334, 629-634.

29 T. Peppel, M. Koeckerling, M. Geppert-Rybczynska, R. V. Ralys, J. K. Lehmann, S. P. Verevkin and A. Heintz, Angew. Chem., Int. Ed., 2010, 49, 7116-7119.

30 B. Mallick, B. Balke, C. Felser and A.-V. Mudring, Angew. Chem., Int. Ed., 2008, 47, 7635-7638.

31 Z.-L. Xie, A. Jelicic, F.-P. Wang, P. Rabu, A. Friedrich, S. Beuermann and A. Taubert, J. Mater. Chem., 2010, 20, 9543-9549.

32 S. Tang, A. Babai and A.-V. Mudring, Angew. Chem., Int. Ed., 2008, 47, 7631-7634.

33 Z.-L. Xie, H.-B. Xu, A. Gessner, M. U. Kumke, M. Priebe, K. M. Fromm and A. Taubert, J. Mater. Chem., 2012, 22, 8110-8116.

34 K. Lunstroot, K. Driesen, P. Nockemann, L. Viau, P. H. Mutin, A. Vioux and K. Binnemans, Phys. Chem. Chem. Phys., 2010, 12, 1879-1885.

35 L. Li, Y. Yang, R. Fan, Y. Jiang, L. Wei, Y. Shi, J. Yu, S. Chen, P. Wang and B. Yang, J. Power Sources, 2014, 264, 254-261.

36 P. Zhang, Y. Gong, Y. Lv, Y. Guo, Y. Wang, C. Wang and H. Li, Chem. Commun., 2012, 48, 2334-2336.

37 A. Chinnappan, H. Kim, C. Baskar and I. T. Hwang, Int. J. Hydrogen Energy, 2012, 37, 10240-10248.

38 A. Branco, L. C. Branco and F. Pina, Chem. Commun., 2011, 47, 2300-2302.

39 A. Babai, S. Pitula and A.-V. Mudring, Eur. J. Inorg. Chem., 2010, 4933-4937.

40 J. Wu, Z. Tang, Y. Huang, M. Huang, H. Yu and J. Lin, J. Power Sources, 2014, 257, 84-89.

41 Y. Zhang, Z. Sun, C. Shi and F. Yan, RSC Adv., 2016, 6, 7046070467.

42 H. Li, S. Li, Y. Zhang and F. Yan, RSC Adv., 2016, 6, 346-352.

43 M. K. Nazeeruddin, A. Kay, I. Rodicio, R. Humphry-Baker, E. Mueller, P. Liska, N. Vlachopoulos and M. Graetzel, J. Am. Chem. Soc., 1993, 115, 6382-6390.

44 H. Tian, X. Jiang, Z. Yu, L. Kloo, A. Hagfeldt and L. Sun, Angew. Chem., Int. Ed., 2010, 49, 7328-7331.

45 R. Bajpai, S. Roy, P. Kumar, P. Bajpai, N. Kulshrestha, J. Rafiee, N. Koratkar and D. S. Misra, ACS Appl. Mater. Interfaces, 2011, 3, 3884-3889.

46 J.-H. Yum, E. Baranoff, F. Kessler, T. Moehl, S. Ahmad, T. Bessho, A. Marchioro, E. Ghadiri, J.-E. Moser and C. Yi, Nat. Commun., 2012, 3, 631.

47 J. Liu, X. Yang, J. Cong, L. Kloo and L. Sun, Phys. Chem. Chem. Phys., 2012, 14, 11592-11595.

48 A. Hagfeldt, G. Boschloo, L. Sun, L. Kloo and H. Pettersson, Chem. Rev., 2010, 110, 6595-6663. 
49 M.-H. Kim and Y.-U. Kwon, J. Phys. Chem. C, 2009, 113, 17176-17182.

50 M. F. Shlesinger and E. W. Montroll, Proc. Natl. Acad. Sci. U. S. A., 1984, 81, 1280-1283.

$51 \mathrm{~J}$. Texter and M. Lelental, Langmuir, 1999, 15, 654-661.

52 F. Fabregat-Santiago, J. Bisquert, G. Garcia-Belmonte, G. Boschloo and A. Hagfeldt, Sol. Energy Mater. Sol. Cells, 2005, 87, 117-131.

53 J. Dong, J. H. Wu, J. B. Jia, L. Q. Fan, Z. Lan, J. M. Lin and Y. L. Wei, J. Power Sources, 2016, 336, 83-90.

54 J. H. Huo, J. H. Wu, M. Zheng, Y. G. Tu and Z. Lan, Electrochim. Acta, 2016, 187, 210-217.
55 S. M. Feldt, G. Wang, G. Boschloo and A. Hagfeldt, J. Phys. Chem. C, 2011, 115, 21500-21507.

56 H. Dong, Z. Wu, A. El-Shafei, B. Xia, J. Xi, S. Ning, B. Jiao and X. Hou, J. Mater. Chem. A, 2015, 3, 4659-4668.

57 Y. Zhang, N. Zhou, K. Zhang and F. Yan, J. Power Sources, 2017, 342, 292-300.

58 M. K. Kashif, J. C. Axelson, N. W. Duffy, C. M. Forsyth, C. J. Chang, J. R. Long, L. Spiccia and U. Bach, J. Am. Chem. Soc., 2012, 134, 16646-16653.

59 M. K. Kashif, M. Nippe, N. W. Duffy, C. M. Forsyth, C. J. Chang, J. R. Long, L. Spiccia and U. Bach, Angew. Chem., Int. Ed., 2013, 52, 5527-5531. 